\title{
De oorlog, de grens en de herinnering
}

Citation for published version (APA):

Beckers, B. V. A. (2019). De oorlog, de grens en de herinnering: herinneringsculturen van de Tweede Wereldoorlog in Roermond en omstreken. [, Maastricht University]. Maastricht University. https://doi.org/10.26481/dis.20190214bb

Document status and date:

Published: 01/01/2019

DOI:

10.26481/dis.20190214bb

Document Version:

Publisher's PDF, also known as Version of record

\section{Please check the document version of this publication:}

- A submitted manuscript is the version of the article upon submission and before peer-review. There can be important differences between the submitted version and the official published version of record.

People interested in the research are advised to contact the author for the final version of the publication, or visit the DOI to the publisher's website.

- The final author version and the galley proof are versions of the publication after peer review.

- The final published version features the final layout of the paper including the volume, issue and page numbers.

Link to publication

\footnotetext{
General rights rights.

- You may freely distribute the URL identifying the publication in the public portal. please follow below link for the End User Agreement:

www.umlib.nl/taverne-license

Take down policy

If you believe that this document breaches copyright please contact us at:

repository@maastrichtuniversity.nl

providing details and we will investigate your claim.
}

Copyright and moral rights for the publications made accessible in the public portal are retained by the authors and/or other copyright owners and it is a condition of accessing publications that users recognise and abide by the legal requirements associated with these

- Users may download and print one copy of any publication from the public portal for the purpose of private study or research.

- You may not further distribute the material or use it for any profit-making activity or commercial gain

If the publication is distributed under the terms of Article $25 \mathrm{fa}$ of the Dutch Copyright Act, indicated by the "Taverne" license above, 


\section{Summary}

\section{War, memory and the border}

\section{Memory cultures of the Second World War in Roermond and vicinity}

This book describes the various ways in which the border town of Roermond commemorates the Second World War, how aspects of it changed over time and how they relate to the alleged national memory culture. I have focused on the annual commemorative March

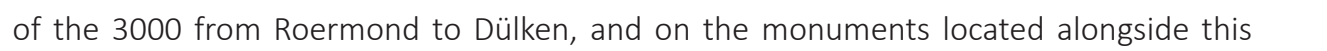
route in memory of the traumatic experiences of forced labour in 1944 and early 1945 . I have also analysed poetry as monument and I have looked into localized transfers and individual memories of eyewitnesses and commemorators. Three chapters are devoted to individuals - Jan Cox, Olga Lewels-Medwedowa and Jan Huyskens - and how they lived through, experienced and remembered the war. These oral histories make my research radically local: they zoom in on individual memory and, at the same time, illuminate aspects of collective local history.

The memory culture of Roermond is especially interesting because of its proximity to the border. Until the outbreak of the war in 1940 the German border was not experienced as a strong, physical demarcation. Roermond and its surroundings have a long history of transnational economic relations with German border towns. Moreover, people spoke similar dialects on both sides of the border. Thus, the attitude towards the eastern neighbours was different in the periphery than elsewhere in the Netherlands. However, the last phase of the war was relatively violent in Roermond. While large parts of the Dutch South were already liberated in the autumn of 1944 , the Allied forces stagnated on the west side of the river Maas while the German army remained east of the river, in and around Roermond. That winter the Germans brought a reign of terror over the city. On 30 December 1944 approximately 3000 local men between 16 and 60 years old had to turn themselves in and were deported as part of the last phase of the Arbeitseinsatz. These men were forced to march through the snowy landscape to Dülken, where they spent a harrowing night at the cycle track there, herded together, in the open air, surrounded by gunners before being moved to Wuppertal. Bystanders from Dülken witnessed the 30000 men being marched through town and harshly treated at their local cycle track. Some offered them warm soup and coffee, an act of kindness with symbolical meaning, as oral history interviews have shown. Next morning the prisoners were separated and put to work in factories in the Rhineland and the Ruhr area. These events, the arrest of the 3000 men and the subsequent transportation across the border, popularly termed 'March of the 3000 ', is at the heart of the local memory culture of Roermond in its different phases and the transnational commemoration activities that began in the $1990 \mathrm{~s}$. 
Historians Frank van Vree and Rob van de Laarse have proposed a periodization of the dynamics of the cultural memory of the Second World War in the Netherlands. According to Van Vree, in the immediate post-war years, cultural memory focused on fallen soldiers and resistance groups and evolved around Christian and national sentiments. During the $1960 \mathrm{~s}$ a shift took place, in which the war was understood as a histdisicontuinity: Auschwitz was seen as a radical departure from national and Christian traditions. The fate of the Jews - largely downplayed before that time - took centre stage in memories of the war. At the end of the $1990 \mathrm{~s}$ another shift announced itself in the form of a European perspective on the war, while other victims of the Nazi regime - homosexuals, Sinti and Roma - had already claimed public attention for their fate. A pluralistic politics of memory commenced, in which displacement and forced labour were finally acknowledged as traumatic war experiences.

My thesis looks into these dynamics, not on a national but on a local and regional level, in the Roermond border region to be precise. The identification of distinctive changes in commemorations as summarized above has been certainly helpful, but I propound that we need to remain open to exceptions to these supposedly general patterns. In the $1950 \mathrm{~s}$ and 1960 s forced labourers were not seen as victims, let alone as subjects of national commemorative activities. They were even suspected of collaboration. It wasn't until the 1980 s that their fates received any general attention. My research, however, shows that the Roermond memory culture has a different dynamic. Forced labour was a dramatic phenomenon in Roermond in 1944 that affected almost everyone. Women, children and other family members witnessed the roundup of local men and boys. In the first decade after the war the group of 3000 were at once at the centre of attention, during commemorations and as subjects of public speeches and monuments. In Roermond there was also never any doubt about the violent nature of forced labour. This is one of the differences I have been able to observe, by comparing national and regional commemorations. There are also similarities, such as the European turn in het mid-1 $990 \mathrm{~s}$. Yet, in the periphery these shifts have a slightly alternative set-up. Most significantly, the Jewish community was very small, which indirectly meant a delay in attention for the Shoah. Finally, commemorations together with the Germans were a much more common - and less contested - phenomenon.

In the first chapter of this book I outline my theoretical framework, drawn from the field of memory studies, studies of localised transfer and histoire croisée. I am critical of the assumed general validity of national frameworks and I claim that a regional perspective sheds light on the abundance and complexity of memory. The next chapter (2 ) is the first life story, the one of Jan Cox, who has lived his entire life directly at the border. A long empirical chapter ( 3 ) shows that memory culture is by definition diverse and multi-layered. The three case studies in this chapter focus on monuments in honour of the March of the 3000 - one in Roermond, one at the border and one in the German town Dülken. 
They offer three unique microhistories: from the influence of contemporary gendered esthetical discourse on the sculptor, municipality and audience, to grassroots initiatives meeting Europeanist town mayors, to local mythmaking and Verg a $n g$ en $h$ eitsb ewä Itig $u n g$. Diversity is inherent to the conception, creation and reception of public monuments. My close readings of these monuments reveal the multiple layers of meaning they display and the way in which these meanings come to life in the rituals and stories connected to them.

The same goes for the three case studies that are combined in chapter 5 , on local poets writing about memories of the war. In terms of literary style and choice of subject Jo Hansen, Harjo Wong and Paul van der Goor can hardly be compared, but their combined contribution to public memory paint a picture of a dynamic local literary field. Poetry is often ignored as a commemorative device, but in the regional - more oral - culture of Roermond it plays a considerable role. Chapter 4 unfolds the biography of Olga LevelsMedwedowa, a prisoner from the Ukraine, who had to work for the Germans in Roermond and stayed on after the war, while chapter 6 presents the life of poet Jan Huyskens. The conclusion again focuses on the way in which regional history sheds light on the nonuniversality of national discourse. If I have made a case that the counter-voices speaking from Roermond might be part of a whole choir of counter-voices from different peripheral regions, my work has been worthwhile. 